Meta

Journal des traducteurs

Translators' Journal

\title{
Restoring Freud: Some notes on P. Mahony's essay
}

\section{Margrit M. Sixel}

Volume 39, numéro 2, juin 1994

La traduction vue de l'extérieur - Translation: a view from the outside

URI : https://id.erudit.org/iderudit/004166ar

DOI : https://doi.org/10.7202/004166ar

Aller au sommaire du numéro

Éditeur(s)

Les Presses de l'Université de Montréal

ISSN

0026-0452 (imprimé)

1492-1421 (numérique)

Découvrir la revue

Citer cet article

Sixel, M. M. (1994). Restoring Freud: Some notes on P. Mahony's essay. Meta, 39(2), 325-327. https://doi.org/10.7202/004166ar

\section{Résumé de l'article}

Dans ce commentaire, l'auteur approuve la démarche de Mahony parce que son examen de certains problèmes liés aux traductions, généralement incontestées, de Freud par Strachey met en lumière l'importance, en traduction, du point de vue et de l'idéologie du traducteur. L'auteur regrette, par contre, que, pour son étude, Mahony se soit trop souvent arrêté sur des choix lexicaux.
Tous droits réservés (C) Les Presses de l'Université de Montréal, 1994
Ce document est protégé par la loi sur le droit d'auteur. L’utilisation des services d'Érudit (y compris la reproduction) est assujettie à sa politique d'utilisation que vous pouvez consulter en ligne.

https://apropos.erudit.org/fr/usagers/politique-dutilisation/ 


\title{
RESTORING FREUD: SOME NOTES ON P. MAHONY'S ESSAY
}

\author{
MARGRIT M. SIXEL \\ Queen's University, Kingston, Canada
}

\section{Résumé}

Dans ce commentaire, l'auteur approuve la démarche de Mahony parce que son examen de certains problèmes liés aux traductions, généralement incontestées, de Freud par Strachey met en lumière l' importance, en traduction, du point de vue et de l'idéologie du traducteur. L'auteur regrette, par contre, que, pour son étude, Mahony se soit trop souvent arrêté sur des choix lexicaux. States:

In a short essay entitled: "Freud Misunderstood and Misread", Robertson Davies

Freud's writings, like psychoanalysis itself, tend to emphasize and confirm whatever a man truly is; but partly read and much misunderstood, they beget a barren pessimism which is not a true, philosophic pessimism, and which is good for nothing at all (1972:70).

After having read Mahony's essay, one might add that the misunderstanding of Freud's writings is not only caused by an inadequate reading of Freud's work, but also by the distortions that his theories suffered in translation.

In his well researched essay, Mahony deals with some of these problems as they can be found, for instance, in Strachey's widely accepted translation. Furthermore, Mahony raises some interesting points with regard to the language that Freud used in his psychoanalytic writings.

One can only agree with Mahony's quest that a translator should be aware of "the important yet sometimes subtle differences [...] between his views and those of the person translated", in order to be able to avoid any deformations of the original text. Mahony convincingly demonstrates that different ideologies and intentions influenced Strachey's translation not the least with the purpose of establishing psychoanalysis as a science.

The difficulty of determining whether psychoanalysis belongs either to the humanities or to the sciences is as old as psychoanalysis itself. A contemporary of Freud, Alfred Döblin, like Freud a physician himself, but unlike Freud a well known author of fiction, had this to say about Freud's Das Ich und das Es (The Ego and the Id): "Es [diese Gedankengänge] sind fesselnde und kluge, höchst persönliche Spekulationen, nicht so sehr wissenschaftliche Arbeit." (These [thoughts] are captivating and intelligent, highly personal speculations, not so much [the outcome of] scientific work) [my translation] (1990: 264).

Even though this characterization of The Ego and the Id cannot be generalized and certainly not be applied to all of Freud's works, it can serve as yet another example for the difficulty of categorizing the intellectual status of psychoanalysis and of doing justice to the language that Freud used. To put the above quotation in the proper perspective, it is perhaps necessary to add that Döblin - although distancing himself to a certain degree from Freud's theories - held Freud in high esteem. The well informed reader may recall that Freud received the most prestigious literary prize of the German language, the Goethepreis of the city of Frankfurt in 1930. Döblin was one of the members of the selec- 
tion committee who spoke and wrote very much in favour of Freud. Döblin was also chosen to give the lecture in honour of Freud's seventieth birthday in the Berlin Academy.

It is in this context that I find Mahony's interpretation of Freud's own conception of the field as a natural science especially interesting. Mahony suggests that Freud did not use the term natural science ironically or in an iconsistent manner, but rather in an "anticipatory way, ... as a serious aspiration about the future" of that discipline.

Freud's style has been admired widely by scientists and non-scientists alike, and it might quite possibly be true that some grammatical qualities of the German language 'furthered Freud's psychoanalytical thinking', as Mahony quotes Grubrich Simitis. Mahony states that Grubrich-Simitis lists as one of the specific traits of the German language 'the many verb-forms to express the passive mode'. But is it not so that the passive mode is more favoured in the English language than in German? Admittedly though, the German language of today uses the passive mode more frequently than was the case in Freud's day and age (see Sanders 1990b: 167).

It is a well known fact that the use of language seems to constantly undergo changes. Words whose meaning were known in Freud's time by the majority of his listeners and readers may not be known today. Let us take, for example, the meaning of the verb erkennen (recognize, know), of which Mahony rightfully says that it can also be used in the biblical carnal sense. But which of today's readers would know this meaning? Thomas Mann, the famous author and, like Döblin, also a contemporary of Freud, used erkennen in the carnal sense in his Joseph novels. Interestingly enough, the company that republished these novels in 1974 thought it necessary to explain the now antiquated meaning of this word in a footnote.

With regard to psychoanalytic translations, Mahony suggests to identify in footnotes the "meaning of words in the original text that might have escaped the conscious awareness of the author". Even though Mahony himself calls this a risky entreprise, one would have to ask whether it is at all a feasable one. How to tell, for example, that Freud was not aware of the fact that in Viennese dialect Feign (fig) was a term for vagina, when he mentioned a Feigenblatt (fig leaf) in connection with a case history in his article Fetishism? Does the very fact that Freud did not draw the attention of the reader to this possible interpretation of Feign necessarily mean that it had escaped his own attention?

Another example for Freud's unconscious derivatives is found by Mahony in the root of the word überzeugen (convince) which is used surprisingly often in the case history of the Wolf Man. I agree with the author that the frequent use of the word is an indication of the fact that Freud wanted to convince his patient and his reader of what he had to say. But I would argue that it does not indicate more than that. It is true that zeugen, the root verb in überzeugen, means besides to witness also to procreate, but, in this case, the variable prefix $\ddot{u} b e r$ combines with the root verb zeugen to form a new inseparable prefix verb with a new meaning, namely to convince, like the author correctly states. There is no other appropriate German word to convey the same idea. Therefore one might perhaps wonder, whether Mahony does not read too much into Freud's frequent use of überzeugen. These remarks are not intended to reject Mahony's suggestion to add linguistically explanatory footnotes to the translations of Freud's works; they might be helpful indeed.

Of course, what Mahony says about the psychoanalyst who is "lure[d] ....into being both translator and traitor", could also be said about the translator who is always embedded in his own subjectivity. - It is the merit of Mahony's essay to have pointed out some of the problems with the generally undisputed translation of Strachey's. 


\section{REFERENCES}

DAVIES, R. (1972): A Voice from the Attic, Toronto, McClelland and Stuart.

DÖBLIN, A. (1990): "Psychoanalyse von heute", Kleine Schriften II, A. W. Riley (Ed.), Olten und Freiburg im Breisgau, Walter Verlag.

SANDERS, W. (1990b): Gutes Deutsch - Besseres Deutsch. Stillehre der deutschen Gegenwartssprache, Darmstadt, wissenschaftliche Buchgesellschaft. 